\title{
Kano Model for Identification Car Modification Features of Mobile Application
}

\author{
Muchamad Sugarindra $^{1}$ and Rian Notia Pratama ${ }^{2}$ \\ 182 Industrial Engineering, Universitas Islam Indonesia, Indonesia
}

\begin{abstract}
Modification was an activity to replace the object more attractive especially car modification. Lately, car modification become the one of the promising business since that were providing high profits. The owner of car look for the accessories for their car frequently. Then, the owner of car modification should increasing their facility to make the consumer satisfied. Furthermore, if the consumer satisfied with the service than it provided high profit. For increasing high profit than the owner of car modification should made the innovation. One of the innovation was car modification with mobile application (apps.) by Kano model. The aims of this study was to identify the features in car modification using Kano model. Kano model used to identify consumer needs that divided into 3 category. There are must be, one dimensional and attractive. The result from open questionnaire would be proceed by Kano model. This study revealed that feature of selection car body colour, feature of selection lamp model and feature engine cap model of into one dimensional category, feature of selection car velg, and matching the tire into must be category and feature of selection cutting sticker, and selection of bumper model into attractive category, and priority to develop are feature of selection car body colour, cutting sticker and selection of bumper model. This category should be the reference to be the resource for car modification apps.
\end{abstract}

\section{Introduction}

In this era, business competitions in Indonesia were getting strict. From that reason above business people should have some strategic that the product would be accepted in the market. One of the strategic which used by the business people were providing the best services and expanding the market in unreached area [1]. As well as business competition in car market. Lately, based on Gabungan industri kendaraan bermotor Indonesia (Gakindo) the sales of car on 2016 reached 1, 06 million. It increased about 4,5\% from year 2015 to 2016. This finding shows that the consumers of car were increasing. Department of design and sales have the high contribution to increase the car sales. The consequence of high sales was swelling of the machine shop. It was for not only machine maintenances but also car modification. Generally, Car Company releasing original car. However, some of consumer needs to modify their car for better performance although small or huge modification. Modification was the activity, which changed the object to be more interesting. The car modification such as changing the colour of car or alloy wheels. Lately, business modification very promising. Some of machine shop got turnover around 40-50 million per month and profit about $30 \%$ from that [2].

Because the growths of workshop then the owner must to attract the consumer with good services and low price. Nowadays, even though the consumer got good services and price, they could not satisfices the consumer. It happened because of the first target was they satisfied about the result even though they got high price. If they were not satisfied yet, they would remain to modify their car until pleased. If that happened consequently the consumer would spending a lot of money. For keep away from repeated modification and good services accordingly the workshop need applications (apps.) for car modification on android based. This app. could help the consumer with simulation modification on android. With that, simulation would be helpful for consumer. These apps. Will help the consumer to choice the modification and for workshop workshop would give the best services for consumer.

To create the apps., needs identification for user. There are model to apps. identification. One of them is Kano model. Kano model used to identify the consumer needs frequently. This model could give the priority for the needs based on three category. [3], [4], [5], [6]. [7]. Kano model is methods of overcoming bias of result from survey to find consumer needs traditionally [8]. In the Kano model there are 3 main requirements that affect the needs or customer satisfaction is must be requirement, one dimensional requirement, and attractive requirements [9]. Must be requirement was the basis requirement or minimal criteria that should be full filled by the produce. However if the requirement weren't that will not affect the product; one dimensional requirement was if the fulfilment more completed then the costumer more 
pleasure and attractive requirements was if they weren't then the product or services couldn't influences but if they were could be increasing the consumers satisfaction. Those requirements would determine the apps. Which is necessary or not.

From the reason above, the purposes for this study was to identify the app., of car modification which required by the workshop owner and consumer. These apps., be expected to improve the profit for the workshop owner, improving the consumer satisfaction, save cost for consumer and reduce the wasted work.

\section{Material and Methods}

\subsection{Research Design}

Design of this study was survey by using primary and secondary data.

\subsection{Data Collection}

These data collected by interview with open questionnaire for primary data and study literature for secondary data. The questionnaire content was about the features, which needed in these apps. and desire analysis about the desire for car modification apps. Study literature would support the information about apps. These studies have four questionnaires that distributed to the consumers. First questionnaires were the open questionnaires which used to know the customer needs on information systems which would be created; second questionnaires was the questionnaires for the decision level, are they valid enough to be attributed for design; third questionnaires was Kano model questionnaires which ask about functional and dysfunctional questions, the purposes for this Kano model questionnaires were to identification the features which needed in this apps. such as positive for functional and negative for dysfunctional question; fourth questionnaires ask about the features specification which proposed to car modification apps.

\subsection{Subject}

Subject on this study were the consumer who has ever had modification their car and the owner of workshop, which served car modification with inclusion criteria, was the people, which could make the decision by age range between 17-35 years old. The number of samples based on the formula 1 and the minimum sample based in formula 2 [10]:

$$
\mathrm{n}=\frac{\mathrm{Z}^{2} \cdot \mathrm{P}(1-\mathrm{p})}{\mathrm{E}^{2}}
$$

The formula of number sampling ( $\mathrm{n}$ : number of sample; $\mathrm{Z}$ : level of confidence; $\mathrm{P}$ (1-p): variation of population; E: sampling error) [10].

$$
\mathrm{n}=\frac{1,645^{2} \cdot 0,5(1-0,5)}{0,1^{2}}
$$

$$
\mathrm{n}=67,65 \sim 68 \text { sample }
$$

\subsection{Data processing and analyses}

After data were collected, then the data processing and analyses were done. The data that obtained would be analyses by validity and reliability using Pearson Product Moment. The data was valid if $\mathrm{p}$ value $>0.05$ and reliable if $r$ count $>r$ table the criteria of reliability were $0,00-$ 1,19: reliability was very low; $0,20-0,39$ : low reliability; $0,40-0,59$ : moderate reliability; $0,60-0,70$ : high reliability; $0,80-1,00$ : very high reliability.

\subsubsection{Kano model category}

The valid and reliable data would be process with Kano model for evaluation attribute. These methods to determine the attribute for the customer satisfaction then categorization were needed. The result of categorization would be used for features of apps. The evaluation of Kano model by input the data based on evaluation Kano model table (Table 1).

Table 1. Kano model evaluation [11]

\begin{tabular}{|c|c|c|c|c|c|c|}
\hline \multicolumn{2}{|c|}{ Consumer needs } & \multicolumn{5}{|c|}{ Dysfunctional } \\
\hline \multirow{4}{*}{ Functional } & & L & E & N & T & D \\
\cline { 2 - 7 } & L & Q & A & A & A & O \\
\cline { 2 - 7 } & E & R & I & I & I & M \\
\cline { 2 - 7 } & N & R & I & I & I & M \\
\cline { 2 - 7 } & T & R & I & I & I & M \\
\cline { 2 - 8 } & D & R & R & R & R & Q \\
\hline
\end{tabular}
A : Attractive
$\mathrm{O}:$ One dimensional
L : Like
$\mathrm{M}:$ Must be
E : Expect
I : Indifference
$\mathrm{N}$ : Neutral
$\mathrm{R}$ : Reverse
$\mathrm{T}$ : Tolerance
Q: Questionable
D : Dislike

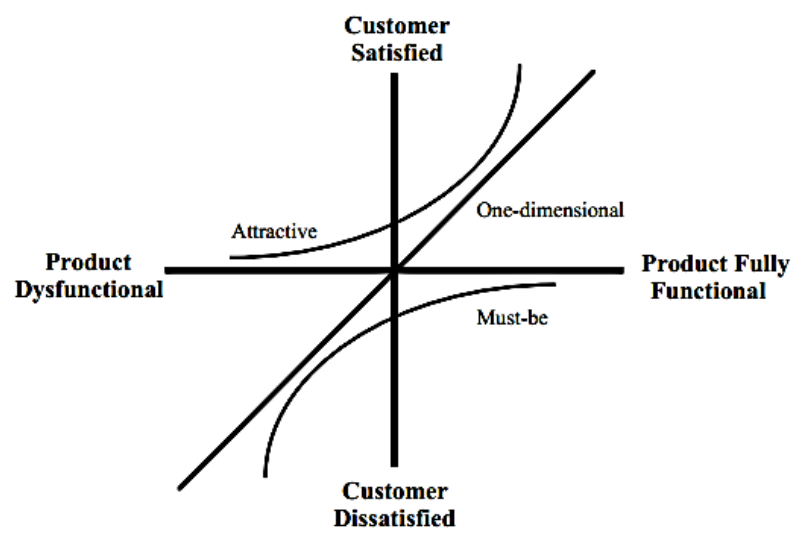

Figure 1. Kano Diagram [12] 
In the Kano model, there are 5 categories of quality factors: must-be, one-dimensional, attractive, indifference and reverse which each have different characteristics and levels of influence on consumers (M, O, A) [3], Indifference (I): this feature will not have an impact on consumers and; Reverse (R): a feature that if held will cause dissatisfaction on the consumer.

Kano model can know the influence of each attribute by identifying relative values to meet user satisfaction or not. In the same conditions, Kano model can be separated into two conditions, namely customer satisfaction and customer dissatisfaction following formula $3 \& 4$ [11]:

Customer Satisfactions $(\mathrm{CS})=\mathrm{A}+\mathrm{O} /(\mathrm{A}+\mathrm{O}+\mathrm{M}+\mathrm{I})$

Customer Dissatisfactions $(\mathrm{CD})=\mathrm{O}+\mathrm{M} /(\mathrm{A}+\mathrm{O}+\mathrm{M}+\mathrm{I})$

If $\mathrm{CS}$ value is closed to 1 , then attribute increasingly influence consumer satisfaction, If CS value is closed to 0 , that means that attribute does not affect consumer satisfaction. If the $C D$ value is closed to -1 then the attribute if not met will greatly affect customer satisfaction and if close to 0 means that the attribute has no effect on customer disappointment [13]

\subsubsection{Conclusion and recommendation}

After the step have done, furthermore the features for apps. Were decided.

\section{Result and discussion}

\subsection{Feature attributes determination}

From the open questionnaire about feature attribute, the subject explained that these feature were needed. They are features of selection car Body Colour (BC), selection of Car Velg model (CV), selection of Tire model (T), selection of colour Car Seat (CS), selection of Cutting Sticker (CSt), selection of design Interior for Audio (IA), selection of Bumper Model (BM), selection of Windshield Glass (WG), selection of Lamp Model (LM), selection of Cap Engine model (CE), and selection of Steering Wheel model (SW). These results would be needed as attributes for car modification app.

\subsection{Validity}

Table 2. Validity and reliability test of feature attributes for car modification app.

\begin{tabular}{|c|c|c|c|c|c|}
\hline $\begin{array}{c}\text { Feature } \\
\text { attributes }\end{array}$ & $\begin{array}{c}\text { R- } \\
\text { table }\end{array}$ & $\begin{array}{c}\text { R- } \\
\text { Count }\end{array}$ & $\begin{array}{c}\text { Expla } \\
\text { nation }\end{array}$ & $\begin{array}{c}\text { Relia } \\
\text { bility }\end{array}$ & $\begin{array}{c}\text { Expla } \\
\text { nation }\end{array}$ \\
\hline BC & 0.235 & 0.473 & valid & 0.830 & reliable \\
\hline CV & 0.235 & 0.460 & valid & 0.830 & reliable \\
\hline T & 0.235 & 0.544 & valid & 0.830 & reliable \\
\hline CS & 0.235 & 0.613 & valid & 0.830 & reliable \\
\hline CSt & 0.235 & 0.602 & valid & 0.830 & reliable \\
\hline IA & 0.235 & 0.689 & valid & 0.830 & reliable \\
\hline BM & 0.235 & 0.672 & valid & 0.830 & reliable \\
\hline
\end{tabular}

\begin{tabular}{|c|c|c|c|c|c|}
\hline WG & 0.235 & 0.606 & valid & 0.830 & reliable \\
\hline LM & 0.235 & 0.742 & valid & 0.830 & reliable \\
\hline CE & 0.235 & 0.663 & valid & 0.830 & reliable \\
\hline SW & 0.235 & 0.635 & valid & 0.830 & reliable \\
\hline
\end{tabular}

The results of open questionnaire about the feature attributes have been done validity and reliability test. The result shows that all of the features attributes were valid and reliable (Table 1).

\subsection{Kano model category}

Table 3. Features attributes category for car modification app. By Kano model

\begin{tabular}{|c|c|c|c|c|c|c|c|c|}
\hline Attributes & A & O & M & I & R & Q & $\begin{array}{c}\text { Total } \\
(\mathbf{n})\end{array}$ & Category \\
\hline BC & 9 & 46 & 8 & 6 & 1 & 0 & 70 & O \\
\hline CV & 10 & 15 & 37 & 8 & 0 & 0 & 70 & M \\
\hline T & 8 & 16 & 34 & 5 & 6 & 1 & 70 & M \\
\hline CS & 4 & 17 & 8 & 38 & 3 & 0 & 70 & I \\
\hline CSt & 39 & 12 & 8 & 10 & 1 & 0 & 70 & A \\
\hline IA & 15 & 11 & 8 & 32 & 3 & 1 & 70 & I \\
\hline BM & 32 & 18 & 6 & 12 & 1 & 1 & 70 & A \\
\hline WG & 8 & 13 & 6 & 37 & 6 & 0 & 70 & I \\
\hline LM & 10 & 32 & 9 & 14 & 5 & 0 & 70 & O \\
\hline CE & 15 & 28 & 10 & 14 & 3 & 0 & 70 & O \\
\hline SW & 14 & 20 & 6 & 25 & 5 & 0 & 70 & I \\
\hline
\end{tabular}

Based on table 3, selection of car velg model $(\mathbf{C V})$, and selection of tire model including categories must-be. Feature of selection car body colour (BC), selection of lamp model and selection of cap engine model (CE) including categories one-dimensional. Selection of cutting sticker (CSt), selection of bumper model (BM) including categories attractive. Selection of colour car seat (CS), selection of windshield glass (WG), selection of steering wheel model (SW) including categories indifference. Indifference category has low influence for customer satisfaction.

After obtained the categorization of each attribute, continued processing data to determine the level of consumer satisfaction of product features based on the formula 3 and 4 . Tabulation data can show in table 4 :

Table 4. Satisfaction level of respondents.

\begin{tabular}{|c|c|c|c|}
\hline Attributes & Category & CS & CD \\
\hline BC & O & 0,797 & $-0,783$ \\
\hline CSt & A & 0,739 & $-0,290$ \\
\hline BM & A & 0,735 & $-0,353$ \\
\hline LM & O & 0,646 & $-0,631$ \\
\hline CE & O & 0,642 & $-0,567$ \\
\hline SW & I & 0,523 & $-0,400$ \\
\hline AI & I & 0,394 & $-0,288$ \\
\hline T & M & 0,381 & $-0,794$ \\
\hline CV & M & 0,357 & $-0,743$ \\
\hline WG & I & 0,328 & $-0,297$ \\
\hline CS & I & 0,313 & $-0,373$ \\
\hline
\end{tabular}


Base on table 4 found attributes include to the priority category to develop, because these category can influence customer satisfaction. Feature selection car body colour became the first priority, feature of selection cutting sticker became the second priority and feature of selection bumper model became third priority.

Feature which has been identified from this research continued with observation and identify special feature for workshop owner. The result of observation was found that the selected features need to add the spare part price. Then, the consumer can calculate directly how much it will cost to modify his car. This apps in the design connected with the database owner of the workshop to know the inventory spare part, invoices to customers and monthly reports to the owner of the workshop.

\section{Conclusion}

Kano model effective to divide attributes into 3 categories, making it easier for programmers to prioritize the attributes that should be developed. The features application that recommended for car modification could be divided are:

1. Must be category: feature of selection car velg, feature of selection tire.

2. One dimensional category: feature of selection car body colour, feature of selection lamp model

3. Attractive category: feature of selection cutting sticker, and selection of bumper model.

4. Priority to develop are feature of selection car body colour, feature of selection cutting sticker and selection of bumper model.

5. The addition of a price list to selected features for the consumer user interface, inventory features, invoices and monthly reports to the user interface of the workshop owner.

6. Further research can be done in making the application and testing usability of application design that has been made

\section{References}

1. Ulus, A. A. 2013. Bauran Pemasaran Pengaruhnya terhadap Keputusan Pembelian Mobil Daihatsu pada PT. Astra International Manado. Universitas Sam Ratulangi, Manado. Jurnal EMBA ISSN 2302-1174 Vol. 1 No. 4, pp.1134-1144

2. Meraup untung bisnis modifikasi mobil, http://bandung.bisnis.com/read/20110611/3/57387/m eraup-untung-bisnis-modifikasi-mobil, accessed on a date 6th April, 2018

3. Hashim, A.Md.; Dawal, S.Z.Md. (2012). "Kano model and QFD integration approach for Ergonomic Design Improvement". International (summer) Conference on Business Innovation and Technology Management, Vol.57, pp.: 22 - 33.

4. Zong, L.; Yu, S.; Li, B. (2013). "The model building research of product innovation design quality based on QFD and KANO”. Trans Tech Publications, Switzerland, Vol. 271-272, pp.: 1467 - 1472.
5. Choirumah, Moses L. Singgih, 2014, Pengembangan Model Integrasi QFD-Kano-Axiomatic DesignFuzzy Goal Programming Serta Aplikasi Triz Dalam Memaksimalkan Kepuasan Dan Meminimalkan Biaya Pengembangan Produk, http://digilib.its.ac.id/public/ITS-paper-401452510100044-paper.pdf accessed on a date 15th May 2018

6. Shinta Oktriviani,Sari Wulandari, Ika Arum Puspita, 2017, The Need Analysis Of I-Gracias Application Using The Integration Of Web Usability And Kano's Model (Study Case On By Telkom University Engineering Faculty College Student ), e-Proceeding of Engineering : Vol.4, No.3 December 2017

7. Aprilia P.D, Amani H, Wulandari S., 2017 Needs Analysis Of E-Commerce Website Services On Dkantin.Com Using Integration E-Service Quality And Kano, e-Proceeding of Engineering : Vol.4, No.3 December 2017

8. Huang, J. 2017. Application of Kano Model in Requirements Analysis of Y Company's Consulting Project. American Journal of Industrial and Business Management, pp. 910-918.

9. Tan, K. C., and Pawitra, T. A. 2001. Integrating SERVQUAL and Kano's Model into QFD for Service Excellence Development. Managing Service Quality Vol. 11 No. 6, pp. 418-430

10. Eriyanto. 2007. Teknik Sampling Analisis Opini Publik. Yogyakarta: PT. LkiS Pelangi Aksara.

11. Berger, C.; Blauth, T.; Boger, C.; Burchill, G.; Du Mouchel, W.; Pouliot, F.; Richter, R.; Rubinoff, A.; Shen, D.; Timko, M.; Walden, D. (1993). "Kano's methods for understanding customer-defined quality". Center for Quality Management Journal, Vol. 2 (4), pp.: $3-36$

12. Walden, D. 1993. A Special Issue on Kano's Methods for Understanding Customer Defined Quality. The Center for Quality of Management Journal, pp. 3-35.

13. Hasan M., 2016 Analisis Kebutuhan Robot Rehabilitasi Pasien Pasca Stroke dengan Menggunakan Metode Kano, JITI, Vol.15 (2), December 2016, 151 - 15 